\title{
Evaluation of the Super League Team's Competition Analysis before and after the COVID-19 Outbreak Is Given
}

\author{
M. Onur Sever (Corresponding author) \\ School of Physical Education and Sport, Department of Coaching Training \\ Gümüşhane University, Turkey
}

Tel: 90-542-218-0305-29000Ｅ-mail: m.onursever@gmail.com

\begin{abstract}
Ömer Zambak
School of Physical Education and Sport, Department of Coaching Training

Gümüşhane University, Turkey

Tel: 90-541-334-0885 E-mail: omer_zambak@yahoo.com
\end{abstract}

Received: December 26, 2020 Accepted: January 25, 2020 Published: February 2, 2021

doi:10.5296/jei.v7i1.18111 URL: https://doi.org/10.5296/jei.v7i1.18111

\begin{abstract}
The paper is aimed to determine whether there is a loss of performance by comparing the competition values of the Super League team before and after the COVID-19 epidemic. In order to reduce the performance losses of the athletes due to lack of training, 60-75 minutes of self-weight training was applied during the quarantine period. Paired t test was used for statistical analysis. A statistically significant difference was found in the Total Distance, High Intensity Distance, Sprint Distance, High Speed Distance, Number of High Intensity Runs, Number of Sprints, Number of High Speed Runs, Average Speed, Total Distance in Possession, Total Distance Out of Possession, Total Distance Ball Out of Play, High Intensity Distance in Possession, High Intensity Distance Out of Possession, High Intensity Distance Ball Out of Play, Sprint in Possession, Sprint Out of Possession, Sprint Ball Out of Play, High Speed Distance in Possession, High Speed Distance Out of Possession, High Speed Distance Ball Out of Play values of the athletes compared to $p<0.05$. As a result, it has been observed that the training of super league football players with their own body weight during the quarantine period positively affects their performance during the season.
\end{abstract}


Keywords: COVID-19, Football, Education, Pandemic

\section{Introduction}

The new type of Coronavirus Disease (COVID-19) first appeared in Wuhan Province, China in late December 2019. It is a virus identified on January 13, 2020 as a result of research on a group of patients. Main symptoms of the respiratory tract are seen as fever, cough, and shortness of breath. The outbreak was initially detected in those in the seafood and animal market in this area. Later, it spread from person to person and spread to other cities in Hubei province, especially Wuhan, other provinces of the People's Republic of China and other world countries. Coronaviruses are a large family of viruses that can cause illness in animals or humans. In humans, several coronaviruses are known to cause respiratory infections, ranging from the common cold to more severe diseases such as Middle East Respiratory Syndrome (MERS) and Severe Acute Respiratory Syndrome (SARS). The New Coronavirus Disease is caused by the SAR-CoV-2 virus.

Although it has been reported that there may be asymptomatic cases with symptoms, their rate is unknown. The most common symptoms are fever, cough and shortness of breath. In severe cases, pneumonia, severe respiratory failure, kidney failure and death may occur. In the first months of 2020, the virus spread rapidly, forcing many countries into a quarantine process where freedom of movement was restricted (TC Ministry of Health, 2020a, 2020b).

Covidien-19 as it is in Turkey and Spread of Pandemic Process was published by the Ministry of Health of the Republic of Turkey and, as indicated in the data page is updated daily; Covidien-19 first cases in Turkey, it was found on March 11, 2020 (TC Ministry of Health, 2020b). May 12, 2020, the total number of tests performed in Turkey, as 16,013,974; The total number of cases from COVID-19 on the same date, 411,055; The total number of deaths was reported as 11,418. In mid-March, when the first case was detected, the daily average number of tests, which is 2-3 thousand, has recently reached 150 thousand 141 . Still, the number of patients recovered in 19 cases in Turkey-Covidien is also well above the world average. As of November 15, 2020, the total cases worldwide were 53,507,282 of the total cases in Turkey it seems hardly to be 1\% of this number (TC Ministry of Health, 2020a).

The World Health Organization (WHO) declared the epidemic as a pandemic after the meeting they held, declaring that the world is facing a serious problem (WHO, 2020). This decision taken by the World Health Organization has caused worldwide concern and fear. For this reason, countries have adopted very severe restrictions, including the curfew, and canceled many organizations. Despite the strict measures taken, with the addition of the inability to control the number of cases and deaths due to the COVID-19 pandemic (Zandifar \& Badrfam, 2020), it was decided by the country federations to play the matches without spectators in order to prevent the spread of the pandemic, especially football (Çifçi \& Demir, 2020).

Football is increasing its sphere of influence as football players and spectators in the world, and with this interest, a competitive environment has been created between teams and countries. With the help of sports sciences developing day by day, an increase in the 
performance of football players has occurred. Performance is the ability of an athlete to demonstrate his ability and capacity in the best way he undertakes during training or competition (Arısoy et al., 2020).

Football is a sport of interaction (cooperative-position) between players, so training without other players will be largely out of context and far from the demands of real competition (Mon-Lopez, et al., 2020).

The matches were canceled on March 19, 2019 due to the COVID-19 epidemic that affected the whole world after the TFF Super League, whose start and end date was planned to be August 10, 2018 and May 19, 2019, was played for 26 weeks. After TFF's announcement, the TFF super league matches were postponed (the remaining 8 weeks of matches) with an uncertain date (depending on the COVID-19 process). Later, the spread rate of COVID-19 was followed and it was decided to play the remaining 8-week matches, starting on 12 June 2019 for the 12-week inevitable break. In this process, it is known that football players must maintain their performance in order to start the matches (TFF, 2020).

Training; It is a planned and scientific education process that aims to increase the physiological, psychological, mental, technical, tactical, characteristics of human. Performance elements can be developed with a planned and systematic training and have positive effects on the energy generation system. In addition, the cardiovascular system improves with training, the aerobic strength of the athletes is improved and the resistance to fatigue increases. Nerve-muscle harmony is improved with training and Strength increases. Capabilities such as coordination, flexibility, mobility, skills are improved. In addition to these developments, the technical, tactical, mental and psychological characteristics of the athlete are reported (Bompa \& Haff, 2015).

\subsection{Detraining}

Detraining, It is the case of a decrease and interruption in the duration, frequency and intensity of the exercise performed to maintain the gains resulting from the training (Hyaat et al., 2019).

The amount of reversibility of physiological adaptations that occur in exercise training; It depends on the individual's training status, genetic characteristics, how much the intensity and frequency components of the exercise are reduced and how long the exercise is left (Gelen et al., 2020). It is especially recommended for high-level athletes to reduce the lack of training stimulus due to the epidemic, instead of stopping training completely in order to reduce the negative effects on athlete performance. Previous gains begin to decline rapidly with a short break to training (Bompa \& Haff, 2015).

Mujika and Padilla (2000a, 2000b) discussed the effects of short and long-term detraining periods on the organism as seen in Tables 1 and 2. 
Table 1. The effects of the short-term detraining period on the organism (first 4 weeks)

\begin{tabular}{|l|l|l|}
\hline \multicolumn{2}{|c|}{ Declining Varieties } & Increasing Varieties \\
\hline Maximal oxygen consumption & High density lipoprotein & Maximum Heart rate \\
\hline Blood volume & Lactate threshold & Heart rate \\
\hline Exercise Stroke volume & Bicarbonate level & Average blood pressure \\
\hline Maximal Cardiac output & Muscle glycogen level & Ventilation threshold \\
\hline Ventricular mass & Capillary density & Maximal respiratory change rate \\
\hline Maximal respiratory volume & Oxidative enzyme activity & Sub-maximal respiratory change rate \\
\hline Oxygen pulse & Glycogen synthesis activity & Postprandial lipemia \\
\hline Durability performance & Mitochondrial ATP production & Low density lipoprotein \\
\hline Insulin-mediated glucose uptake & Average fibril cross section & Submaximal blood lactate \\
\hline GLUT-4 protein content in muscle & EMG activity & \\
\hline Muscle lipoprotein lipase activity & Force-Power performance & \\
\hline
\end{tabular}

Table 2. Effects of long-term detraining period on organism (4-8 weeks)

\begin{tabular}{|l|l|l|}
\hline \multicolumn{2}{|c|}{ Declining Varieties } & Increasing Varieties \\
\hline Maximal oxygen consumption & Muscle glycogen level & Maximum Heart rate \\
\hline Blood volume & Capillary density & Sub-maximal Heart rate \\
\hline Exercise Stroke volume & Arteriovenous oxygen difference & Recovery Heart rate \\
\hline Maximal Cardiac output & Oxidative enzyme activity & Ventilation equivalent \\
\hline Ventricular mass & Average fibril cross section & Sub-maximal respiratory change rate \\
\hline Maximal respiratory volume & FT: ST ratio & Average blood pressure \\
\hline Oxygen pulse & Muscle mass & Respiratory exchange rate \\
\hline Durability performance & EMG activity & Submaximal blood lactate \\
\hline Lipolysis & Force-Power performance & \\
\hline High density lipoprotein & & \\
\hline Lactate threshold & & \\
\hline
\end{tabular}

During the epidemic period, it was suggested that people should be mobile by exercising at home as much as possible. Therefore, programs have been prepared for athletes to do at home. These studies include stationary bicycles, treadmills, aerobic exercise and exercises with their own body weights. Aerobic exercises are those that produce low, medium or high cardiovascular tension.

WHO recommends muscle and bone strengthening exercises three times a week and 60 


\section{Macrothink}

minutes of daily physical activity at moderate to vigorous aerobic intensity for children and adolescents (5-17 years) (WHO, 2010). WHO recommends 150 minutes/week of physical activity aimed at strengthening muscles and bones for adults and seniors over 17 years of age with vigorous aerobic exercise intensity 75 minutes/week or twice a week at moderate aerobic intensity intensity (WHO, 2010).

Connolly et al. (2020) suggested in order to prevent cardiovascular, metabolic and musculoskeletal fitness disorders; They suggested gymnastic and aerobic exercise programs. Stationary bicycles, treadmills, and other home-based sports equipment suitable for aerobic training can be used to achieve health effects. This type of exercise provides moderate to vigorous aerobic training when set up as high-intensity self-pace exercise that can be controlled by heart rate monitors or a power output loading program (Bingöl et al., 2020).

The aim of this study is the comparison of the match played after the exercises of untrained Super League footballers taking exercise with their body weights at home during the COVID-19 period and the last match before the isolation period.

\section{Methods}

\subsection{Participants}

Players who are in the TFF Super League Gazişehir Gaziantep Football A Team and have no health problems. The matches of Gazişehir Gaziantep-MKE Ankaragücü and Aytemiz Alanyaspor-Gazişehir Gaziantep were analyzed.

\subsection{Home Exercises during Restriction and Isolation}

During this period, athletes exercised their own body weights at home for 60 to 75 minutes every other day.

\subsection{Measurement Methods and Tests}

During the Competition Athletes's parameters listed below were checked.

Total Distance;

High Intensity Distance $(20 \mathrm{~km} / \mathrm{h}-24 \mathrm{~km} / \mathrm{h})$;

Sprint Distance (> $24 \mathrm{~km} / \mathrm{h})$;

High Speed Distance ( $>20 \mathrm{~km} / \mathrm{h})$;

Number of High Intensity Runs;

Number of Sprints;

Number of High Speed Runs;

Average Speed;

Total Distance in Possession;

Total Distance Out of Possession; 


\section{Al Macrothink}

Total Distance Ball Out of Play;

High Intensity Distance in Possession;

High Intensity Distance Out of Possession;

High Intensity Distance Ball Out of Play;

Sprint in Possession;

Sprint Out of Possession;

Sprint Ball Out of Play;

High Speed Distance in Possession;

High Speed Distance Out of Possession, High Speed Distance;

Ball Out of Play.

\subsection{Statistical Evaluation}

The data obtained in the study were recorded regularly during the competition. The recorded data were transferred to the SPSS 22.0 package program and necessary statistical processes were applied. Normality tests of measurement variables were made. Paired t Test analysis, one of the parametric tests, was performed to determine the difference between the previous and post evaluations of the study group. The significance level of the study was accepted at $p$ $<0.05$.

\section{Findings}

Table 3. Statistical comparison of the Total Distance, High Intensity Distance $(20 \mathrm{~km} / \mathrm{h}-24$ $\mathrm{km} / \mathrm{h})$, Sprint Distance $(>24 \mathrm{~km} / \mathrm{h})$, High Speed Distance $(>20 \mathrm{~km} / \mathrm{h})$ values of the research team's last match before pandemic break and first match after the pandemic break

\begin{tabular}{|c|c|c|c|c|c|c|c|c|}
\hline & \multicolumn{5}{|c|}{ Paired Differences } & \multirow{3}{*}{$\mathrm{T}$} & \multirow{3}{*}{$\mathrm{df}$} & \multirow{3}{*}{$\begin{array}{l}\text { Sig. } \\
\text { (2-tailed) }\end{array}$} \\
\hline & \multirow[t]{2}{*}{ Mean } & \multirow{2}{*}{$\begin{array}{l}\text { Std. } \\
\text { Deviation }\end{array}$} & \multirow{2}{*}{$\begin{array}{l}\text { Std. } \\
\text { Error } \\
\text { Mean }\end{array}$} & \multicolumn{2}{|c|}{$\begin{array}{l}95 \% \text { Confidence } \\
\text { Interval of the Difference }\end{array}$} & & & \\
\hline & & & & Lower & Upper & & & \\
\hline Total Distance & 4361.00000 & 1.41421 & 1.00000 & 4348.29380 & 4373.70620 & 4361.000 & 1 & .000 \\
\hline High Intensity Distance & -37712.00000 & 2.82843 & 2.00000 & -37737.41241 & -37686.58759 & -18856.000 & 1 & .000 \\
\hline Sprint Distance & -60.50000 & .70711 & .50000 & -66.85310 & -54.14690 & -121.000 & 1 & .005 \\
\hline High Speed Distance & 227.50000 & 3.53553 & 2.50000 & 195.73449 & 259.26551 & 91.000 & 1 & .007 \\
\hline
\end{tabular}

Table 3 shows the comparison of Total Distance, High intensity distance, sprint distance and high speed distance values of the super league team with the Paired Sample-t test. 
Statistically significant differences were detected in the values of Total Distance, High intensity distance, sprint distance and high speed distance $(\mathrm{p}<0.05)$.

Table 4. The effects of the long term detraining period on the organism (4-8 weeks)

\begin{tabular}{|l|l|l|}
\hline \multicolumn{2}{|c|}{ Declining Varieties } & Increasing Varieties \\
\hline Maximal oxygen consumption & Muscle glycogen level & Maximum Heart rate \\
\hline Blood volume & Capillary density & Sub-maximal Heart rate \\
\hline Exercise Stroke volume & Arteriovenous oxygen difference & Recovery Heart rate \\
\hline Maximal Cardiac output & Oxidative enzyme activity & Ventilation equivalent \\
\hline Ventricular mass & Average fibril cross section & Sub-maximal respiratory change rate \\
\hline Maximal respiratory volume & FT: ST ratio & Average blood pressure \\
\hline Oxygen pulse & Muscle mass & Respiratory exchange rate \\
\hline Durability performance & EMG activity & Submaximal blood lactate \\
\hline Lipolysis & Force-Power performance & \\
\hline High density lipoprotein & & \\
\hline Lactate threshold & & \\
\hline
\end{tabular}

Table 4 shows the comparison of the Super League team's Number of High Intensity Runs, Number of Sprints, Number of High Speed Runs and Average Speed values with the Paired Sample-t test. Statistically significant differences were detected in the values of Number of High Intensity Runs, Number of Sprints, Number of High Speed Runs and Average Speed ( $\mathrm{p}$ $0.05)$.

Table 5. Statistical comparison of the participants' Total Distance in Possession, Total Distance Out of Possession, Total Distance Ball Out of Play between values of the last match before the and the first match after pandemic break

\begin{tabular}{|c|c|c|c|c|c|c|c|c|}
\hline & \multicolumn{5}{|c|}{ Paired Differences } & \multirow{3}{*}{$\mathrm{T}$} & \multirow{3}{*}{$\mathrm{df}$} & \\
\hline & \multirow[t]{2}{*}{ Mean } & \multirow{2}{*}{$\begin{array}{l}\text { Std. } \\
\text { Deviation }\end{array}$} & \multirow{2}{*}{$\begin{array}{l}\text { Std. } \\
\text { Error } \\
\text { Mean }\end{array}$} & \multicolumn{2}{|c|}{$\begin{array}{c}95 \% \text { Confidence } \\
\text { Interval of the Difference }\end{array}$} & & & $\begin{array}{l}\text { Sig. } \\
\text { (2-tailed) }\end{array}$ \\
\hline & & & & Lower & Upper & & & \\
\hline Total Distance of Possession & 5371.00000 & 1.41421 & 1.00000 & 5358.29380 & 5383.70620 & 5371.000 & 1 & .000 \\
\hline Total Distance Out of Possession & 4389.50000 & .70711 & .50000 & 4383.14690 & 4395.85310 & 8779.000 & 1 & .000 \\
\hline Total Distance Ball Out of Play & -5400.50000 & .70711 & .50000 & -5406.85310 & -5394.14690 & -10801.000 & 1 & .000 \\
\hline
\end{tabular}


Table 5 shows the comparison of the Total Distance in Possession, Total Distance Out of Possession, Total Distance Ball Out of Play values of the super league team with the Paired Sample-t test. Statistically significant differences were detected in the values of Total Distance in Possession, Total Distance Out of Possession, Total Distance Ball Out of Play $(\mathrm{p}<$ $0.05)$.

Table 6. Statistical comparison of the participants' High Intensity Distance in Possession, High Intensity Distance Out of Possession and High Intensity Distance Ball Out of Play between values of the last match before the and the first match after pandemic break

\begin{tabular}{|c|c|c|c|c|c|c|c|c|}
\hline & \multicolumn{5}{|c|}{ Paired Differences } & \multirow{3}{*}{$\mathrm{T}$} & \multirow{3}{*}{ df } & \multirow{3}{*}{$\begin{array}{l}\text { Sig. } \\
\text { (2-tailed) }\end{array}$} \\
\hline & \multirow[t]{2}{*}{ Mean } & \multirow{2}{*}{$\begin{array}{l}\text { Std. } \\
\text { Deviation }\end{array}$} & \multirow{2}{*}{$\begin{array}{l}\text { Std. } \\
\text { Error } \\
\text { Mean }\end{array}$} & \multicolumn{2}{|c|}{$\begin{array}{c}95 \% \text { Confidence } \\
\text { Interval of the Difference }\end{array}$} & & & \\
\hline & & & & Lower & Upper & & & \\
\hline High Intensity Distance in Possession & 281.00000 & 1.41421 & 1.00000 & 268.29380 & 293.70620 & 281.000 & 1 & .002 \\
\hline High Intensity Distance Out of Possession & 76.50000 & .70711 & .50000 & 70.14690 & 82.85310 & 153.000 & 1 & .004 \\
\hline High Intensity Distance Ball Out of Play & -68.50000 & 2.12132 & 1.50000 & -87.55931 & -49.44069 & -45.667 & 1 & .014 \\
\hline
\end{tabular}

Table 6 shows the comparison of the High Intensity Distance in Possession, High Intensity Distance Out of Possession and High Intensity Distance Ball Out of Play values of the super league team with the Paired Sample-t test. Statistically significant differences were detected in the values of High Intensity Distance in Possession, High Intensity Distance Out of Possession and High Intensity Distance Ball Out of Play $(\mathrm{p}<0.05)$.

Table 7. Statistical comparison of the participants' Sprint in Possession, Sprint Out of Possession andSprint Ball Out of Play between values of the last match before the and the first match after pandemic break

\begin{tabular}{|c|c|c|c|c|c|c|c|c|}
\hline & \multicolumn{5}{|c|}{ Paired Differences } & \multirow{3}{*}{$\mathrm{T}$} & \multirow{3}{*}{$\mathrm{df}$} & \multirow{3}{*}{$\begin{array}{l}\text { Sig. } \\
\text { (2-tailed) }\end{array}$} \\
\hline & \multirow[t]{2}{*}{ Mean } & \multirow{2}{*}{$\begin{array}{l}\text { Std. } \\
\text { Deviation }\end{array}$} & \multirow{2}{*}{$\begin{array}{l}\text { Std. } \\
\text { Error } \\
\text { Mean }\end{array}$} & \multicolumn{2}{|c|}{$\begin{array}{l}95 \% \text { Confidence } \\
\text { Interval of the Difference }\end{array}$} & & & \\
\hline & & & & Lower & Upper & & & \\
\hline Sprint in Possession & 199.00000 & 1.41421 & 1.00000 & 186.29380 & 211.70620 & 199.000 & 1 & .003 \\
\hline Sprint Out of Possession & -252.50000 & .70711 & .50000 & -258.85310 & -246.14690 & -505.000 & 1 & .001 \\
\hline Sprint Ball Out of Play & -6.50000 & .70711 & .50000 & -12.85310 & -.14690 & -13.000 & 1 & .049 \\
\hline
\end{tabular}

Table 7 shows the comparison of Sprint in Possession, Sprint Out of Possession and Sprint Ball Out of Play values of the super league team with the Paired Sample-t test. Statistically 
significant differences were detected in the values of Sprint in Possession, Sprint Out of Possession and Sprint Ball Out of Play $(\mathrm{p}<0.05)$.

Table 8. Statistical comparison of the participants' High Speed Distance in Possession, High Speed Distance Out of Possession and High Speed Distance Ball Out of Play between values of the last match before the and the first match after pandemic break

\begin{tabular}{|c|c|c|c|c|c|c|c|c|}
\hline & \multicolumn{5}{|c|}{ Paired Differences } & \multirow{3}{*}{$\mathrm{T}$} & \multirow{3}{*}{$\mathrm{df}$} & \\
\hline & \multirow[t]{2}{*}{ Mean } & \multirow{2}{*}{$\begin{array}{l}\text { Std. } \\
\text { Deviation }\end{array}$} & \multirow{2}{*}{$\begin{array}{l}\text { Std. } \\
\text { Error } \\
\text { Mean }\end{array}$} & \multicolumn{2}{|c|}{$\begin{array}{c}95 \% \text { Confidence } \\
\text { Interval of the Difference }\end{array}$} & & & $\begin{array}{l}\text { Sig. } \\
\text { (2-tailed) }\end{array}$ \\
\hline & & & & Lower & Upper & & & \\
\hline High Speed Distance in Possession & 468.00000 & 1.41421 & 1.00000 & 455.29380 & 480.70620 & 468.000 & 1 & .001 \\
\hline High Speed Distance Out of Possession & -168.50000 & 2.12132 & 1.50000 & -187.55931 & -149.44069 & -112.333 & 1 & .006 \\
\hline High Speed Distance Ball Out of Play & -78.00000 & 2.82843 & 2.00000 & -103.41241 & -52.58759 & -39.000 & 1 & .016 \\
\hline
\end{tabular}

Table 8 shows the comparison of High Speed Distance in Possession, High Speed Distance Out of Possession and High Speed Distance Ball Out of Play values of the super league team with the Paired Sample-t test. Statistically significant differences were detected in the values of High Speed Distance in Possession, High Speed Distance Out of Possession and High Speed Distance Ball Out of Play $(\mathrm{p}<0.05)$.

\section{Discussion}

To the best of the authors of the study, COVID-19 is the first study to evaluate team performance before and after the mandatory break given to football during the epidemic period.

The research shows that after the mandatory break due to COVID-19, the athletes cannot leave their homes and the trainers have prepared some exercise programs that the athletes can do at home to close this period with minimum performance loss. As a result of the exercises performed by the football team with their own body weights at home, some performance values of the team were discussed. According to this; When the values of the last match of the super league team before and the first match after the COVID-19 break, which is an average of 3 months, are examined, statistically significant differences were found in the Total Distace, High Intensity Distance, Sprint Distance, High Speed Distance, Number of High Intensity Runs, Number of Sprints, Number of High Speed Runs, Average Speed, Total Distance in Possession, Total Distance Out of Possession, Total Distance Ball Out of Play, High Intensity Distance in Possession, High Intensity Distance Out of Possession, High Intensity Distance Ball Out of Play, Sprint in Possession, Sprint Out of Possession, Sprint Ball Out of Play, High Speed Distance in Possession, High Speed Distance Out of Possession, High Speed Distance Ball Out of Play values compared to $\mathrm{p}<0.05$. 
When the literature is examined; Mon-Lopez et al. (2020) stated that regarding the sports level of football players, male professional footballers train more days and hours than non-professional players. However, they noted that female professional footballers train more intensely and more days than non-professionals.

Reardon et al. (2019) and Mon-Lopez et al. (2020) stated in their study that moods and emotional intelligence can affect training variables and the performance of top-level football players. As a professional footballer who played in Turkey league COVID-19 to perceive the fear and the stress level is moderate and footballers were not very impressed by this process actually Çifçi and Demir (2020) was stated.

As a result, it was determined that professional football players who could not leave the house due to mandatory restrictions prevented the loss of performance in the work done with their own body weights during this period.

It is generally accepted that there is an overall loss of around $10 \%$ for each week of inactivity (Varandas et al., 2017). In the face of COVID-19, any epidemic or any compulsory situation that will restrain athletes to their homes, it is thought that athletes will at least reduce inactivity with their own bodyweight training and prevent performance loss. When this or a similar situation is encountered, the training should be increased gradually when the athletes return to the season and the risk of injury should be tried to be minimized.

\section{References}

Arısoy, A., Osman, P., \& Karaoğlu, B. (2020). Covid-19 Sürecinde Futbola Dönüş Öncesi Futbolcuların Durumluk Kaygı Düzeyleri İle Psikolojik Performansları Arasındaki İlişki Belirlenmesi: Isparta Örneği. Yalvaç Akademi Dergisi, 5(1), 55-63.

Bingöl, H., Canpolat, B., Demiralp, İ., \& Öncü, H. (2020). COVID-19 Süresince Egzersiz Uygulamaları ve Fiziksel Etkinlik. In Rukuye Aylaz \& Erman Yıldız (Eds.), Yeni Koronavirüs Hastalı̆̆ının Toplum Üzerine Etkileri Ve Hemşirelik Yaklaşımları (pp. 97-102). Malatya: İnönü Üniversitesi Yayınevi.

Bompa, T. O., \& Haff, G. G. (2015). Dönemleme ve antrenman kuramı ve yöntemi (5th ed.). Ankara: Spor Yayın ve Kitabevi.

Çifçi, F., \& Demir, A. (2020). COVID-19 Pandemisinde Türk Profesyonel Futbolcuların COVID-19 Korkusu Ve Kayg1 Düzeylerinin İncelenmesi. Spor ve Rekreasyon Araştırmaları Dergisi, 2(1), 26-38.

Connolly, L. J., Scott, S., Morencos, C. M., Fulford, J., Jones, A. M., Knapp, K., ... Bowtell, J. L. (2020). Impact of a novel home-based exercise intervention on health indicators in inactive premenopausal women: A 12-week randomised controlled trial. European Journal of Applied Physiology, 120(4), 771-782. https://doi.org/10.1007/s00421-020-04315-7

Gelen, M., Serdar, E., \& Nebahat, E. (2020). Detraınıng: COVID-19 Ve Üst Düzey Performans. Milli Eğitim Dergisi, 49(227), 447-464.

Hyatt, J. P. K., Brown, E. A., Deacon, H. M., \& Mccall, G. E. (2019). Muscle Specific 
Sensitivity to Voluntary Physical Activity and Detraining. Frontiers in Physiology, 10, 1328. https://doi.org/10.3389/fphys.2019.01328

Mon-López, D., García-Aliaga, A., Bartolomé, A. G., \& Solana, D. M. (2020). How has COVID-19 modified training and mood in professional and non-professional football players? Physiology \& Behavior, 227, 113148. https://doi.org/10.1016/j.physbeh.2020.113148

Mujika, I., \& Padilla, S. (2000a). Detraining: Loss of Training-Induced Physiological and Performance Adaptations. Part I: Short Term İnsufficient Training Stimulus. Sports Med., 30, 79-87. https://doi.org/10.2165/00007256-200030020-00002

Mujika, I., \& Padilla, S. (2000b). Detraining: Loss of Training-İnduced Physiological and Performance Adaptations. Part II: Long Term İnsufficient Training Stimulus. Sports Med., 30, 145-154. https://doi.org/10.2165/00007256-200030030-00001

Reardon, C. L., Hainline, B., Aron, C. M., Baron, D., Baum, A. L., Bindra, A., ... Derevensky, J. L. (2019). Mental health in elite athletes: International Olympic Committee consensus statement. British Journal of Sports Medicine, 53(11), 667-699. https://doi.org/10.1136/ bjsports-2019-100715

TC Ministry of Health. (2020a). Retrieved November 15, 2020, from https://covid19.saglik. gov.tr/TR-66300/COVID-19-nedir-.html

TC Ministry of Health. (2020b). Retrieved November 15, 2020, from https://covid19.saglik. gov.tr/TR-66135/1-yeni-koronavirus-sars-cov-2-nedir.html

Turkey Football Federation. (2020). Retrieved October 31, 2020, from https://www.tff.org/ default.aspx?pageID $=687 \&$ ftxtID $=33181$

Varandas, F., Medina, D., Gómez, A., \& Della Villa, S. (2017). Late Rehabilitation (On the Field). Injuries and Health Problems in Football (pp. 571-579). Springer, Berlin, Heidelberg. https://doi.org/10.1007/978-3-662-53924-8_50

WHO (World Health Organization). (2010). Global recommendations on physical activity for health.

WHO (World Health Organization). (2020). Coronavirus. Retrieved November 15, 2020, from https://www.who.int/health-topics/coronavirus\#tab=tab_1

Zandifar, A., \& Badrfam, R. (2020). Iranian mental health during the COVID-19 epidemic. Asian Journal of Psychiatry, 51, 101990. https://doi.org/10.1016/j.ajp.2020.101990

\section{Copyright Disclaimer}

Copyright for this article is retained by the author(s), with first publication rights granted to the journal.

This is an open-access article distributed under the terms and conditions of the Creative Commons Attribution license (http://creativecommons.org/licenses/by/3.0/). 